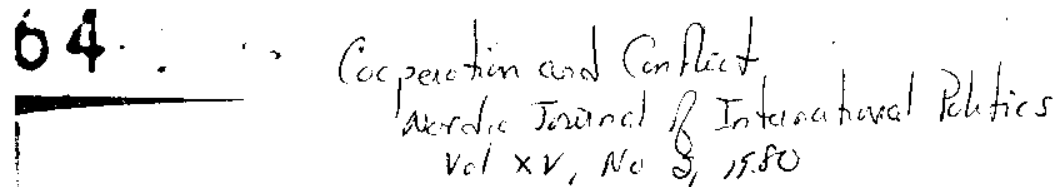

\section{The Illusory Nordic Alternative to Europe}

BO STRATH

Department of History. University of Gothenburg

Strath. B. The Illusory Vordic Alternative to Europe. Cooperation and Conflict, $X V, 1980$, $10.3-114$

Debate and research on Nordic governmental cooperation has for long been premised on the assumption that the impelling forces behind such cooperation are to be found inside the Nordic countries themselves. Nordic cooperation has been regarded as an alternative to Europe. This article proceeds from the assumption that international or external factors have wo be taken more into consideration. They form a framework for the political activities of the Vordic countries and could be characterized as long-term factors. Other relevant Iong-term factors are economic, industrial, and social structures of the Nordic countries. Considering these external and long-term factors does not imply disregarding internal factors and day-to-day events or current affairs, short-term factors. The three dichotomies externallinternal, long-term/short-term, and economic/political factors are used as tools of analysis. A systematic use of the concepts leads to the conclusion that external political and cconomic long-term factors operate centrifugally on Nordic cooperation. Internal political factors have occasionally worked for Nordic cooperation. Yet these internal political factors, as a rule of a short-term kind, have been exceeded by the stronger external political and econonic factors of a long-term kind. There has been no independent Nordic alternative to Europe. This conclusion is based on a long historical perspective.

\section{INTRODUCTION}

For a long time the debate on Nordic cooperation has been much alive in the Nordic countries. There has also been not unimportant research - although descriptive rather than explanatory - on the forms and content of this cooperation. It is astonishing to what extent both debate and research have almost exclusively treated this Nordic cooperation as a purely Nordic problem. The impelling forces for Nordic cooperation have been sought inside the Nordic countries themselves. The explanations of Nordic cooperation - or, if you wish, the nonappearance of Nordic cooperation - have largely been missing.

The purpose of this article is to analyse Nordic cooperation from a somewhat different point of departure than the prevalent one. The intention is systematically to take into consideration factors affecting Nordic cooperation both inside the Nordic countries and in the surrounding world and of both a long-term and short-term kind.

For a successful analysis it is necessary in a more distinct fashion than in earlier research to discern and define these external or international and internal or inter-Nordic factors.

The external or international factors provide a framework for the foreign political activities of the Nordic countries. Of course, this framework is not constant but varies over time. However, change occurs slowly and hardly becomes apparent during a short period of time. Therefore the external factors could be characterized as longterm factors. Other long-term factors of relevance here are the economic, social, and industrial structures of the Nordic countries. These structures also change slowly.

Stating that these long-term factors are relevant does not imply disregarding day-today events or current affairs. Tariffs, balances of payments, competition capability of one country/industry compared with that of other countries/industries, i.e. taxes, wages, energy costs, and so on, are examples of factors that change more rapidly 


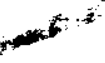

than the long-term ones. They can be referred to as short-term factors. ${ }^{1}$

There is no absolute bordefline between the short-term and the long-term factors and there is interaction between them A shortterm tariff or tax policy may for instance have effects on the long-term industrial structure. For instance, Norwegian industry changed during the 195() from having been very vulncrable to being very competitive.

It goes without saying that the economic and commercial structure of a country is of fundamental importance when analysing its forcign policies. It is necessary to take these economir factors into consideration. However, it is not enough to consider economic and conmercial prerequisites when discussing the loreign pollitical outlook of a country. Iorcign policies are also determined hy conscious political decisions. One could say that the ecomontic factors form a framework imside which different political decison' are concuivable. The economic faums could head to different political decisoms. Thu these pellow al factors mustalon be considered ()t cuere both econonic and pultencal tarters can be of an external or an inlemal kind as inct! a long-kerm or shor H.r.

In my recently pubiviled thesis abou : he

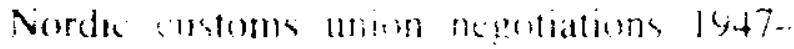
1459 a lerig histormal merpective . Which

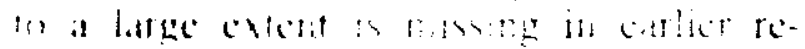

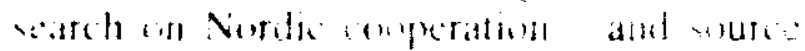
materal mot corfer andiable thate made it

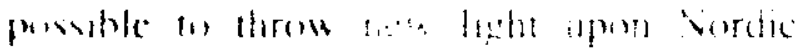

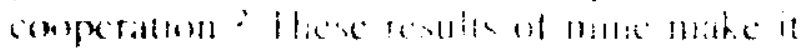

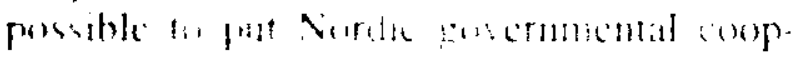

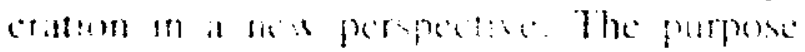

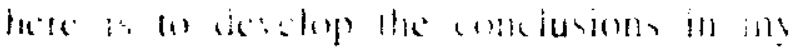

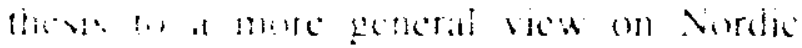

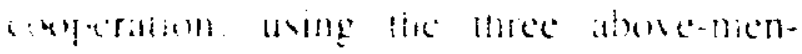

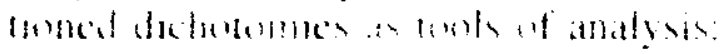

\footnotetext{
Natris and inemal taters.

thag :erm and shonterm facters and comosen and perticisl facters.
}

Ite atempin at Vordi ensomental cooperation will be regarded partly in the light of the international environment and partly in the internal milieu. Both internationaily and internally I will discuss economic and political aspects and discern long-term and short-term factors.

This use of the concepts external and internal, long-term and short-term, and economic and political factors can be regarded as a method to discern explicitly the premises for Nordic governmental cooperation.

\section{THE HISTORY OF NORDIC COOP- ERATION}

The plans for a Scandinavian defence union in 1948-1949, the negotiations concerning a Nordic customs union in 1947-.1959, and the Nordek Plan for a Nordic common market around 1970 are the three post-war examples of how attempts to create Vordic cooperation in more organized forms have failed. The defence mion taiks broke down when Sweden could not accept it as a link with Western military cooperation. Instead of joining a Nordic customs union, the Nordic countries became members of the European Free Trade Association (EFTA) heited hy Great Britain. The Nordek Flan colliped who thentand could not atcept it as a link in one formi or another with the HEC. The three plans ior tordic govcrnmental cueperation were all dependent on developments in the surrounding world

This dependence besmes still nore palpataic in a longer historical perspective. Prusiat, sictory wer Denmark in 1864 meant a sudden end lo Scimlinasism, a mocment regarding Scandibavia as a malural unit nationally, culturally, and wolitically and of the san: kind and $w$ ith the sume bourgeois supporters as. for infince, the Italian unification moverizent at about the same time. Scandinavism received is death-blow in 1864 when the unitedkingtem of Sueden-Norway retused to cume t. Denmatk's assistance.

Dening Wuld War I on the viner hand 
outside pressure gave impetus to Scandinavian unity. During the war the kings and the prime and foreign ministers met several times to consider the situation of the three countries.

With the Soviet Union and Germany weakened as a result of the war, the stimulus to Scandinavian cooperation - or, more correctly, Nordic cooperation, as Finland had now gained its independence disappeared again. During the 1920s Finland was more oriented towards the Baltic countries than towards the Nordic region. The ministerial meetings were no longer as frequent.

The 1930s meant again a development toward more intensitied cooperation. After Hitler's Machtübernahme in 1933 Danish Premier Stauning suggested a Nordic defence treaty. In 1934 the Finnish government of Kivimiki said that it favoured a Nordic neutralit! policy. The Nordic orientation wat an atteimpt to avoid getting into a swpeeze in the case of a Russian-German cinouiter. The Rusian envoy Assmus had told the Finnist Pemier that the Sovid l. :olt if threatcud by Germany. for secunty reasons might have to oceupy parts of Fulan! By disengagement from Comany and drawing closer towards the Nortic countrics. Finland hoped to convince the Soviet Inion of the genuinosess of its newrality policy. As a comsequence of the Finnish anation towards the Nordic area. deliberat as started about a common Finmoh-Swedish defence of the demilitarized Aland Stands in the Batlic

But as extemal fictors had driven the vordic countries wother, so externat fate tors split thon again. Veither Hiler nor Scalin wanted Vordic copperation. In 1937 Stauning abandoned his cartier view and satid that Demark was no longer prepared to be a watch-deg at the siothem border of the Nordic countric. When the USSR in 19.39 vetocel the Aland Plan this was drop ped.

The picture of the allesists at Nordic onstration is one of ant urdutating move- ment with developments in the surrounding world as an impelling force. There does not seem to be any independent impetus inside the Nordic countries themselves towards Nordic cooperation. There was no attempt to intensify cooperation during the 1920 s when the influence from the surrounding world was exceedingly small. If there had been such an independent impetus times should have been very favourable for such a force to work with no disturbing factors from the world around.

Instead of intensified Nordic cooperation during the 1920s there were on the contrary signs of inter-Nordic tensions. When the Swedish foreign minister Carl Hederstierna in an after-dinner speech in 1923 - possibly acting upon the impulse of the moment - as a personal opinion suggested a FinnishSwedish defence union in the event of an unprovoked attack from 'the neighbour in the East', he was forced to resign on account of the ivicut protests. Around 1930 a crisis was throdtening in Danish-Norwegian relations when Norway challenged Danish suprenacy over Eastern (ireenland.

When on the other hand the extertial pressure has been very strong, attempts at cooperation have hroken down. That was the case when the Nordic revion faced a strone Plusia in $186+$ and in the late lo3os when the Virfic countric were serromated by cieminty prepared for war and the USSR much stronger than is decate carlier. This

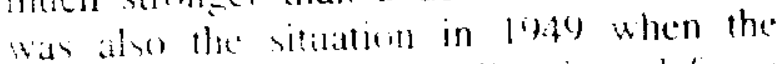

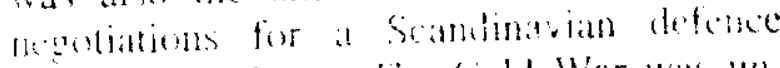
man breke down. The cold War was un der way. The Nordic asca was once of the points of intersecioun of seperpower interests

When ther have been atlempts at Vordic cosperation, ine foreign political situation can be thatachroed as something midway betwes: hicie lwo extremes. External factors hale insuated vordic comperation. Sweden-Norwity assisted Denmark neilataly in the Danish-Prussian conflict in $1 \times 48-1850$. Pruseia was not yet the great power it was to be in 186.4 It should be

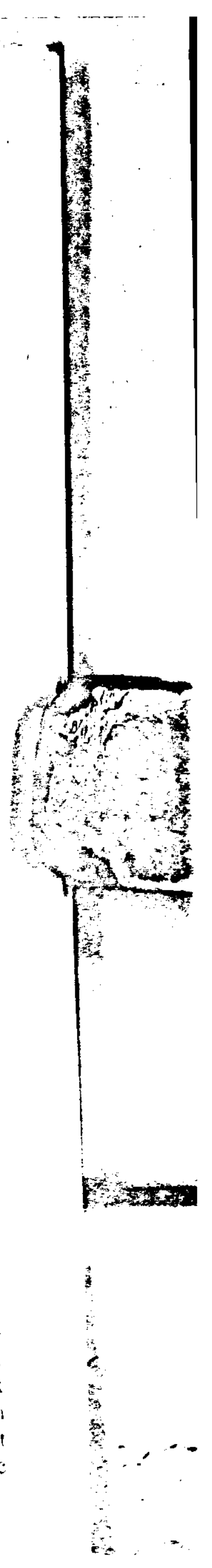


underlined that Sweden-Norway did not intervene on the Danish side until they had learned that Russia intended to' support Denmark diplomatically. World War I meant an external influence on Scandinavian cooperation. The position of the Nordic countries was then not as exposed as during World War II when the strategic factors meant a much more immediate threat to them. In the same way - as will be demonstrated below - the Marshall Plan initiated an attempt at Nordic cooperation. The plan was not considered to imply that the Nordic countries took sides with any of the superpowers in the incipient Cold War. At least not if the participation in the plan occurred under the cloak of Nordic cooperation. But when, at about the same time or somewhat later. it was a question of conneçting a Scandinavian defence union to Western military cooperation the external pressurc crossed the threshold. Consequently the negotiations collapsed.

To sum up: When it has been quiet and peaceful in the surrounding world there has been no Nordic cooperation. An increased activity in the surrounding world which has tended to put the Nordic region, or part thereof, into great power politics has implied incehuives for Nordic cooperation. When these forces have grown stronger, the attempts at cooperation have broken down.

\section{THE NORDIC CUSTOMS UNION NEGOTIATIONS, 1947-1959}

Against this background it is astonishing to what extent debate and research in this area have had a purely Nordic point of teparture. Thus the debate ahout the two Nordic post-war customs union projects has $a$ priori had as a prerequisite the assumption that Nordic economic conperation would be very advantageous for the Nordic countries, despite the fact that all trade statistics indicate that the commercial interests of the post-war period have been in Western Europe, for Finland also in Eastern Europe.

Existing research has not sufficiently dis- cerned external and economic long-term factors when dealing with problems concerning Nordic governmental cooperation. This conclusion is valid not least for the Nordic customs union negotiations of 19471959. In order to demonstrate this and to demonstrate the usefulness of my approach, I will discuss these negotiations from my point of departure in some depth.

The initiative was a direct consequence of the Marshall Plan in the summer of 1947. The small Scandinavian countries needed American capital but wanted to remain neutral in the incipient struggle between East and West. A Scandinavian customs union - Finland was at the time out of the question due to its special relationship with the USSR - was considered as a means of such a policy. ${ }^{3}$ A committee was established for closer investigation. In a preliminary report in January 1950 the committee stated that there was no ground for an agreement.

This was only a fortnight after the US had explained to the three Scandinavian foreign ministers that a regional Nordic customs union would not merit the three countries more Marshall capital. The US wanted not regional but Western European economic cooperation.

The governments did not bury the issue, however. The committee got new instructions in November 1950. The new mandate was restricted to a limited free trade area. In the spring of 1954 the committee rendered its final report. It came to divided conclusions. The Danes and the Swedes argued that there was ground for a Nordic common market-whereas the Norwegians held an opposite viewpoint.

Not even this report resulted in a burial of the issue. Instead it was raised from the expert level to the highest political level. A joint cabinet meeting instructed a new Nordic Economic Cooperation Committee (NECC) to investigate areas where elimination of trade restrictions would imply overwhelming advantages for all three countries.

In 1956 Germany, France, Italy, and the 
Benelux countries had advanced plans for a common market. Other Western European erountries than the Six feared the risk of a trade political split in Western Europe. In the summer of 1956 an association of other countries in the form of a free trade area was suggested as a way of avoiding such a split. An investigation was also decided upon.

From now on the Nordic and the European investigations ran parallel. In July 1957 when the NECC issued its final report covering some 80 percent of inter-Nordic trade and a year later, when it handed over its supplementary report covering the rest of inter-Nordic trade, nothing was decided but to wait for the outcome of the Paris talks on a Western European free trade area.

When the talks had broken down in November 1958 different proposals for alterations to the NECC reports were considered. Simultaneously during the spring of 1959 the governments of the countries left outside the Six customs union were negotiating over an outer European free trade area. When the governments had agreed on such an area - EFTA - the Nordic plan was rejected in July 1959.

The importance of the surrounding world for the freedom of action of the Nordic countries has already been suggested. A framework for the foreign political activities of the countries existed, and its appearance varied with time. During the period studied here such a framework for the foreign policy of the Nordic countries was provided by the Cold War. The framework of the Cold War can be looked upon as an independent variable or as an external factor upon which the foreign policy of the Nordic countries had to depend. The foreign political factors which constitute a framework for the government and other agencies are here of the kind that they determine the development in the long run. The change of such factors occurs slowly and the change hardly becomes clear over a short period. They could be characterized as long-term factors.
Theoretically the foreign political options for alliances were many; but in reality they were limited by long-term geopolitical and historical/political factors such as the importance of the outlets of the Baltic and the areas north of the Arctic Circle, and the interests of the Western powers in Denmark and Norway and of the USSR in Finland in a conflict situation between the two blocs, and with Sweden in an intermediate position. Regarding the options, the Nordic region must of course not be considered as a unity. These long-term factors are centrifugal to Nordic cooperation.

Other long-term factors of relevance here are the economic and industrial structures. As has been mentioned the Nordic countries had their economic interests primarily in Western Europe, Finland also in Eastern Europe. The Nordic area was only of secondary interest. The long-term foreign political factors worked centrifugally on the Nordic region, and so did the long-term economic factors.

Swedish industries were much more advanced than Norwegian industries. Agriculture meant relatively more in Denmark than in the neighbouring countries. Norway, Finland, and Sweden were better provided with raw materials than Denmark. Theoretically Denmark could provide the rest of Norden with agricultural goods but this complementarity remained on paper. An import of Danish agricultural products would have politically impossible effects on the small farmers in the other three countries. Also the social structure was a longterm factor of relevance, as was the longterm industrial structure.

Barbara Haskel has made interesting contributions to the discussion of Nordic post-war governmental cooperation. She goes beyond earlier descriptive research in trying to explain what happened. ${ }^{4}$ She does it in a methodologically interesting way and, more than earlier research, does she put the Nordic area in a European perspective.

Although not explicitly, she uses external 
and intemal factors in her analysis. Her emphasis is, however, on the economic factors. Political factors are hardly considered in a satisfying way. She also disregards the long-term factors affecting the development. A more systematic use of these concepts would probably have brought about more convincing conclusions.

Haskel regards Nordic and European cooperation as different options. From economics she has borrowed the concept of opportunity costs. A Nordic customs union is systematically related to different European market solutions. It was all the time a matter of choosing the most advantageous of different alternatives by measuring the costs of taking one option in terms of other options that could have been followed instead. The cost of choosing one specific option is the benefit foregone by not using

another prevailing option. Haskel describes the negotiations in terms of concepts from bargaining theory. Denmark and Sweden used an expansive strategy, i.e. they thought that the joint benefit could increase in a Nordic customs union, the size of the whole pie could be increased; whereas Norway followed a distributive strategy; i.e. it regar led it to be a matter of settling the shares of the different players, the division of a more or less constant pie.

The difference in strategies resulted in antagonism during the negotiations between Denmark and Sweden on the one side and Norway on the other. The knot was hard to untic as the limited inter-Nordic trade made the incentives small for fundamental changes in the domestic economic policies of the countries. The comparatively small gains at stake did not invite any more farreaching concessions. 5

Haskel concludes that while noneconomic considerations did not preclude, the Nordic market, neither did they enhance its value. The economic prerequisites existed but they were not sufficient. There was a lack of incentives from other political areas to supply the needed lubricant or, with her own words, grease for an agreement. ${ }^{6}$
Haskel's method results in an emphasis on the economic factors. The political factors, which according to her were missing, but necessary to bring about a Nordic customs union, are not analysed in depth.

Haskel builds her analysis on interviews with some 25 central decision-makers in Denmark, Norway, and Sweden. For the rest, the source material is mostly printed reports of the governmental committees and joumal and newspaper articles. Of the voluminous unpublished archive material that remains from the negotiations she has only had access to about five memoranda and notes in the Norwegian Foreign Department. She touches only marginally on the role of Finland. Nor has she used any Finnish sources.

Haskel's study is methodologically interesting. This is true not least in her use of the concepts of political and economic factors. But she does not discuss the difference and the limits between these factors. To Haskel the political factors become simply residual factors which she seizes upon when the economic factors appear to be insufficient to explain what happened.

Whereas the economic factors are easy to explore, the political considerations behind the decisions are not as easily distinguishable in the public and printed material. The question is whether Haskel's. source material leads her to disregard the political factors.

The state secrecy laws make it difficult or impossible to get hold of the unprinted minutes, drafts, and memoranda from the negotiations in the governmental archives. There is however a by-pass. The industrial federations played a very active role in the negotiations. The governments had a great need for the technical knowledge of the federations during the very dynamic development of the market questions. There were frequent and mutual briefings. In the archives of the federations is left a great deal of the same material which is still kept secret in government archives. And as nonpublic organizations, the federations are not 
subject to the state secrecy laws. Through access to the archives of the federations it has been possible to follow the negotiations in detail. The unprinted material there makes it possible to analyse the political and economic factors in the Nordic customs union negotiations. However, the prerequisite for such an undertaking is that some clarification of concepts is made. One has to distinguish between economic and political factors.

In this study economic factors are defined as referring to comparative advantages, possibilities of large scale production, specialization, and increased productivity, improvements of balances of payments, and economic growth. The political factors on the other hand are, among others, security politics and ideological considerations. Furthermore, if a group of countries tries to agree on economic cooperation in order to get a better position and strength in trade negotiations with other countries, the cooperation is looked upon as primarily decided by a political factor. ${ }^{7}$

One also has to distinguish between means and ends when regarding economic and political factors. Of course economic and political factors do interfere, mingled with each other and as means and ends, in a complicated manner.

Theoretically one could as tools of analysis consider the following alternatives:

1. The projected Nordic customs union was an economic or a political end in itself.

2. The projected Nordic customs union was an economic or a political means to an economic or a political end.

To make things even more complicated one has to take into account the fact that, for example, political means to achieve economic ends could appear disguised as economic ends in their own right. In such a case the means has to be regarded as political and the end as economic.

My hypothesis is that the Nordic customs union negotiations were a means to achieve a better position in the European trade negotiations during the 1950s and that they were primarily politically motivated, not economically.

As has been stressed, the political and economic factors are as a rule not quite pure but intermixed in any debate on economic cooperation. It has also been underlined that an essential undertaking is to distinguish them from each other by analysing the debate and the negotiations. But a prerequisite for such an undertaking is that the concepts are used as a point of departure. This approach is different from concentrating on one of them and degrading the other to a residual factor at the end.

The best possibility to test whether Nordic cooperation was economically motivated must be to investigate how those organizations reacted whose whole existence is justified by taking economic - long-term as well as short-term - factors into consideration. The attitudes of the industrial federations to a Nordic customs union are a tool in order to consider if suç a customs union at all or to some extent could be a long-term economic goal in itself. The attitudes are then related to the long-term and short-term factors, and to external and internal factors.

If the industrial federations - with regard to both their long- and short-term interests - were negative or little interested in a Nordic customs union, it is probable, considering their representativity of industry in the Nordic countries, that a Nordic customs union was not economically motivated.

The federations were initially very hesitant about the Nordic customs union project. In 1949 the Federation of Norwegian Industries (NI) expressed a negative viewpoint. It continued to hold this view atl the time up to 1959. The NI regarded the whole existence of Norwegian industry to be threatened by, above all, Swedish industry. The large export enterprises which had less to fear had not much to gain in a Nordic market.

The Federation of Swedish Industries (SI) was sceptical, but not so much on account of the economic consequences. Instead it feared a development toward a planned 
economy led and inspired by Social Democratic governments in all the Scandinavian countries. In purely economic terms the trade associations of the SI had little objection. This made the criticism of the SI somewhat hollow. The head organization began in the early 1950s to speak about the Nordic project in more positive terms. The SI said that economically Sweden had nothing to lose. But a Nordic market would be too small for gains of any importance. For such gains turopean corperation was demanded.

The Federation of Danish Industries (DI) was more pusitive. Repeatedly it expressed a positue viewpoint. At the beginning of 1956 this atritude was suddenly broken, however, after a report by the governmental committec Massive protests against the reforn trom the paper and metal industries mate the If chatige its ipinurifi. From then on the Int held a hestlent vere un the Nordic plan

Ithe thee ferktatum wanted a lareer teuropean market. Hhes argued intensely in

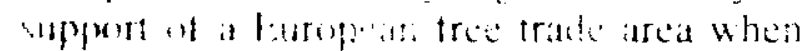

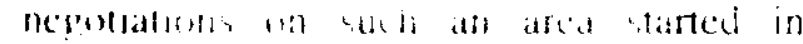

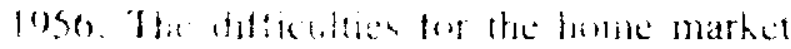

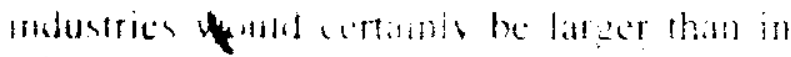

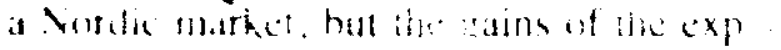

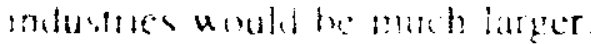

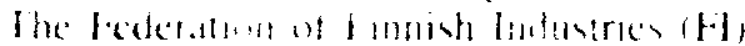

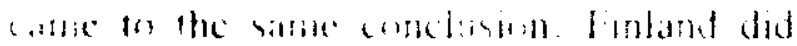

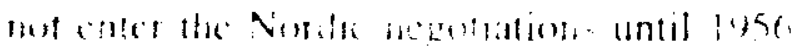

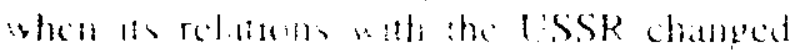

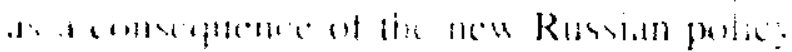

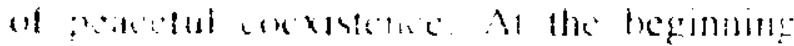

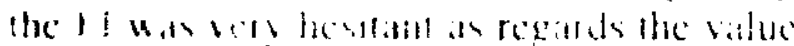

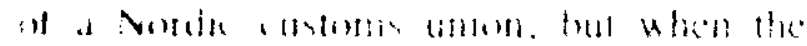

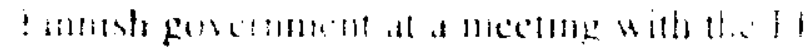

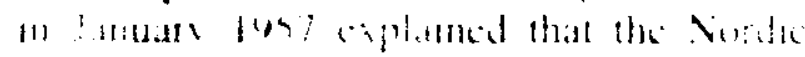

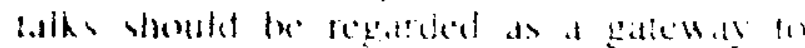

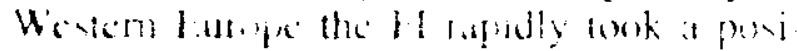

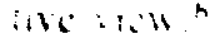

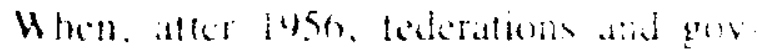

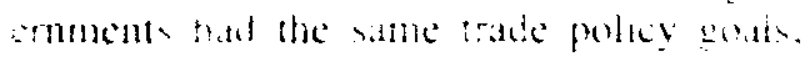
the contive between them hecante ver inense When the fowh hod been jifferent the somaces were of a more formal sharis- ter. After 1956 all four governments began to give priority to increased European economic cooperation, Finland however only indirectly via Nordic cooperation. They began to stress the same economic factors as the federations, which long since had argued that their main interest was in a European market. The antagonism towards a Nordic customs union was put aside. Nordic cooperation became a matter of making participation in European cooperation easier. Nordic cooperation became a matter of tactics. It could at the utmost be an instrument to achieve membership in European cooperation, nothing more.

The attitudes of the industrial federations indicate that a Vordic customs union was not ecomirmically motivated. Was it then politically motivated? And what then was the political aim?

The very urigin of the Nordic project was as has been pointed out - the Marshall plan. The Lnited Stales demanded ecommin: cooperation batween the Euro-

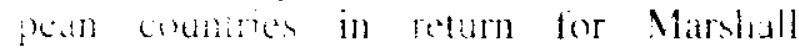
miney. The Vinde customs union plan was intended to demonstrate the interest of the Vordic entuntries in such cooperation. it the same time the plan was it means of avoiding (1) c) cose an association with the Wescern

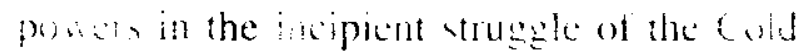
War. The three gowemments wanted to remat outside the blo -huilding. This policy

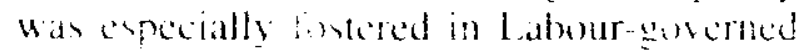
Vortuly and binedern. Demmark hitd at the

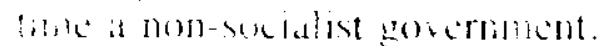

Atter lone the Nordic plan was regaded w a datems of ats an instrument which could mat the vordic countrice a better posion in the Luropein narket ikgotiations. The Sordic negotiations were complately defendent on the Paris alks. Vuak conperat wh itas instrumental loxards a European

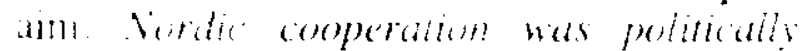

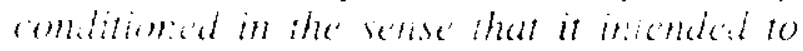

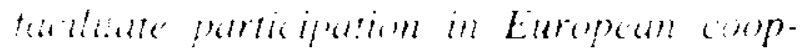
eratem. Vordic conperation was a metsms of abheving non-Vordie go ils.

bito the patem also fits the mushopubli- 
cized close cooperation between the Nordic countries during the GATT round in 1964. This cooperation was in the contemporary political debate frequently interpreted as a new step towards Nordic cooperation but was hardly anything more than a tactical cooperation in order to achieve non-Nordic goals. The same is valid also for the Nordek Plan. Denmark did not conceal that the plan was intended as a bridge to the Common Market. When Finland - on account of its special relationship with the Soviet Union, i.e. an external factor - could not accept this, the negotiations broke down.

But what about the new turn in the Nordic customs union negotiations in 1954? After the experts had disagreed over the possibilities for a Nordic customs union the issue was simply raised to the highest politicai level. This was two years after Marshall aid had ceased and one or two yeurs before the development of the European market plans. There was a dounswing in European economic cooperation. liberalization of arade within the framework of the OEIC and the GAT had got stuck.

The start of the new inquiry in 1954 does not seem to fit very well into the pattern ahove. The Norwegian Labour government initiated the new incestigation. According as the Nonwegian gowanment Nodic rooperation brould be a counterweight to the alliance with the countrics on the continent. The I abour government had rasums for its mithate. A not unimportant left-wing fitetion of the Envernment party objected to Virwegian participation in Wistern military comperation and had to be patified. The fact that the fateris gained influence at about this time shoutd be considered against the batheround of a burgeoning development toitards peaceful coexistence after Stalin's death in 1953. In order to pacily the i.eftang faction Nordic couperation was to the purpose."

Why then did Dennturk and Sweden accept such a Nordic plan? Or did they really accept it? It must be stressed that Nordic coxperation in a concept full of significance in the Nordic region. This makes it a politically interesting idea, which must be treated with some care. This is demonstrated by the fact that the failures of the large post-war schemes for Nordic cooperation have been covered by new initiatives for cooperation, which however have been much less farreaching than the intended unsuccessful plans. The failure of the Scandinavian defence union talks in 1948-49 was followed by a decision on a common passport area, the projected Nordic customs union by the Helsinki treaty in 1962 on intensified cooperation in different areas, and the Nordek Plan by the establishment of a Nordic Ministerial Council. These agreements have meant nothing but the development of a pragmatic cooperation. For politicians who have failed to agree on Nordic cooperation in more spectacular forms, such pragmatic cooperation has had the merit of appealing to public opinion. Nordism - defined as the idea of bringing the. Nordic countries together as much as possible - is mostly prevident among intellectuals. But it is widespread enough to be a political factor of some importance. ${ }^{10}$

Against this background it is understandable that Denmark and Sweden found it hard to openly reject the Norwegian initiative in lint after the failure of the expert contmintec. luat it very soon hecame obviwus that Dcimlark and Sweden had no intention of yielding to the Norwegian ideas. The Norucgian plan was abortive. The Nordic negotiations had already got stuck when developments on the continent made it possible to adlapt the Nordic plan to the market negeriations there

In a waty the forcign political situation around :954 was reminiscent of that of the 1920s. Activity in the outside world was low. I de-escalation of the Cold War had skev.y begun after Stalin's death. Western Luropean econonic cosperation under Marshall aid had become sluck, as has been mentioned. The same can be sitid about Western Iuropean political coopcration. In 1954 the projectid Luropean Defence 
Community was discarded. If there had been an independent impetus for Nordic cooperation inside the Nordic countries :-: themselves the time should have been favourable around 1954. But as during the 1920s there was no such cooperation. The Norwegian swallow did not make a summer.

If the governments treated the Nordic customs union mainly as a political means, the industrial federations - on account of the very nature of their function as interest groups - wanted to consider it as a matter of economic advantage or disadvantage. Regarding the customs union from this viewpoint, the federations came to other conclusions than did the governments taking other factors into consideration. After 1956 the divergencies concerning the Nordic customs union receded into the hackground. The man task was now Europe. This was in line with the interests of the industrial federations.

Barbara Haskel concludes that the economic prerequisites for Nordic economic cooperation existed but that the cooperation failed because there was no political lubricant

My conctysion is the opposite. The polltical prerequisites existed, such in, among others, the Nordic plan as an instrument towards the real gral. participation in luropean cooperation. There was economic lubricant to some extent, hut far from cmough to make the Virdic customs union an modependent goal.

A peint of departure for Haskel is to regand Nonde and I uropean coopetation as - Hefferent optems. Mly thess is that there did not exst any Nordac allernative to Luropean counomic couperation. At most, it could be an clement of it.

\section{N rONCILSIONS}

Cisperatom between the Nordic countries has been an objes! of great merest in the pollite al debate. Nordic corperation has ion seldem been desorned as wmething un- ique. It has often been contrasted with, for instance, European cooperation. My case study of the projected Nordic customs union during the 1950 s reveals that Nordic cooperation was not an alternative to European cooperation but at most an element of it. The conclusion is based on a long historical perspective. The concepts of long-/shortterm, external/internal, and economic/ political factors are used to discern explicitly the premises for Nordic cooperation. The attitudes of the Nordic industrial federations - motivating their whole existence by taking economic long- and shortterm factors into consideration - have been the tools for deciding if a Nordic customs union could be an independent economic goal.

In my study it has been difficult to trace an independent and inherent will to achieve Nordic economic cooperation except on the level of individuals. There the influence of Nordism as an active force is manifest. But it has hardly been the stimulus of the governments. It has only contributed to keeping the idea of Nordic cooperation alive among politicians. The incitements have been impulses from the outside world, incitements in the form of threats or possibilities. When the external forces have grown too strong they have, houever, not brought about an impulse in a unifying direction. The Nordic countries realized the impetus for Nordic cooperation in 1947 but the realization was

as ever - dependent on developments outside Norden.

A systematic use of the concepts of externalinternal, long-/short-term, and economicipolitical factors leads to the concluvion that external political and cumonic long-term factors operate centrifugally on Nordic cooperation. Only during some short periods of time when the cxiernal forces have neither been too small nor too strong does there seem to have been a stimulus fron the outside world towards Viordic couperation. For the rest the $x$ ficwrs hwe worked against such cooperation. The conomic factors have meant a major 
economic and commercial interest for the Nordic countries in Westem Europe, for Finland also in Eastern Europe, not in the Nordic region. Long-term political factors of external provenance such as the Swedish neutrality policy, the Danish and Norwegian post-war Western alignment, and the Finnish special relationship with the Soviet Union, have also worked in a centrifugal direction. These basic conditions have meant a long-term trend contrary to Nordic governmental cooperation.

Political short-term factors have on occasion worked for an intensified attempt at Nordic cooperation. Here the treatment of different cooperation projects as a political tool in a European context has been pointed out. The same is valid for the increased stress on Nordic cooperation in Norway in 1954 for domestic political reasons. Within the category of internal political factors could also be mentioned the role of Nordism. These political and internal factors, as a rule of a short-term kind, have, however, been exceeded by the stronger external and conomic long-term tactors. The external international factors have played a dominating role in Nordic attempts at governmental cooperation.

They have all the time decided the room for manocuvrability of the Nordic countries. Internal factors have been of quite a subordinate importance. There have certainly been weak impelling forees for Nordic govermmental cooperation of a more spectacular kind rrside the Nordic countries themselves, but they have been outweighed by centrifugal forces from the surrounding world working in a disintegrating direction, as the use of the concepts long- and short-term factors in a long historical perspective indicates.

\section{NOTES}

1 Bernt Schiller has developed the concepts of long- and short-term factors in a study of research problems in contemporary history. He regards the long-term factors as primary in relation to the short-term ones. The long-term or primary factors are, and this is a vital point in his argument, not anything that can be taken for granted. They are dependent on the point of departure for each study, or in Schiller's own words, 'determined by the hypothesis formulated'. Bernt Schiller, 'Shortage and Plenty. Long- and Short-term Factors and Research Problems in Contemporary History', Scandinavian Journal of History, Vol, 1, No. 1 (1976), pp. 164-168.

2 Bo Stråth, Nordic Industry and Nordic Economic Cooperation, Almqvist \& Wiksell International, Stockholm 1978. This is report No. 1 from the research project Interest Organizations and Internationalism, University of Gothenburg. The project was established in 1970. From the very start it has heen headed by Profesior Bernt Schiller and has been funded mainly by the Bank of Sweden Terentenary Foundation. The general aim of the project has heen to study conditions influencing the international relations of interest organizations of agriculture, industry, and labour. To achieve this a long historical perspective and a comparative analysis involving national, regional, and global levels have frequently been used. For an outline of the project, also including the interpretation of the history of vordic cooperation is setched athove, sce Bermit Schiller, Interest Organizations and Internationaliom a Research Project on Contenisurary History (forthooming).

${ }^{3}$ Strath, up cit., pp. 6,581 .

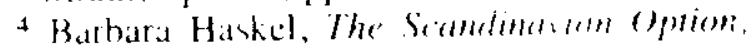
Lniversitenfortaget, ()olo 1976. Amomy wher and carticr studies on Nordic conperattion which are of relewnee here could he mentioned stantey

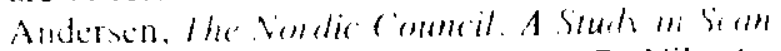
dimarian Resismalom. I condon 1967; Nib Andren, Vordisk Integration - Synpunkter exh Prohlemestrningar', Internasjomal Pelitikh.

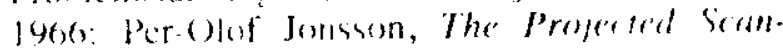
dimenan cirsems Inion 1947 1959. unpub-

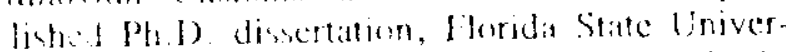
iiy 1964: Arthur Momennory, from a North-

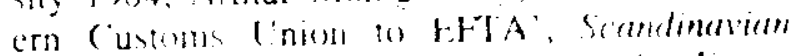

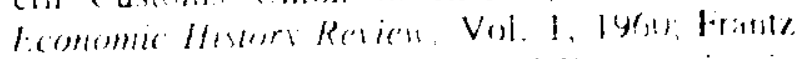

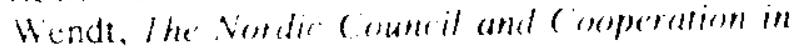
Soundinaria. (inpeshaten 1959 


\section{Bo Stråth}

5 Haskel, op. cit., p. 98.

"Ihid.. pp. 129-130.

7 Strath. op. cit., pp. 60-61. The distinction between economic and political factors is used in earlier rexarch on Scandinavian cooperation although the concepts have not been more closely defined. Cl. Ake Holmberg. 'Sverige och den ekonomiska skandinavismen vid 1860-talets början'. in Studier tillägnade (urt Weibull, Gothenburg 1946, p. 224; and Montgomery, op. cit.
A It was the Minister of Trade Aare Simonen who explained how the Nordic negotiations should be interpreted. Simonen was the leader of a Social Democratic minor breakaway faction which, as distinguished from the major faction, had the Kremlin's confidence. Whether Simonen's green light to Western Europe via Nordic cooperation had been reinsured in the USSR has not heen possible to determine.

${ }^{9}$ Străth, op. cit., pp. 105-109.

10) Ibid., pp. 43-47. 